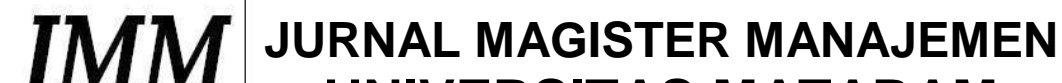 UNIVERSITAS MATARAM UNRAM VOL. 6 No. 1 MARET 2017
}

\section{PENGARUH KOMITMEN ORGANISASIONAL DAN MOTIVASI KERJA TERHADAP KINERJA ANGGOTA BADAN KESWADAYAAN MASYARAKAT (BKM) PADA PROGRAM PNPM KOTA MATARAM}

\author{
Rosmiati $^{1}$ \\ Thatok Asmony ${ }^{2}$ \\ Hermanto $^{3}$
}

\begin{abstract}
This research was conducted in the community self-reliance organization. This research is aimed at determining the effect of organizational commitment and work motivation of members of Community self-reliance organization of urban national program of community empowerment in Mataram. The population of this research are 556 from which 85 respondents were selected. The data were analyzed using multiple linear regression. The research showed that organizational commitment and work motivation subsequently affect positively and significantly the performance of members of Community self-reliance organization of urban national program of community empowerment in Mataram.
\end{abstract}

Keywords: organizational commitment, work motivation, performance

\section{PENDAHULUAN}

Aktivitas dari sumber daya manusia diketahui memainkan peranan sentral dalam mengaitkan kemampuan atau kinerja karyawan dengan kinerja (performance) perusahaan (Yound, 1996: 836). Dengan kata lain, tercapainya tujuan lembaga hanya dimungkinkan karena upaya para pelaku yang terdapat pada organisasi atau lembaga tersebut. Gomes (1995: 135) mengutip pernyataan dari Bernardin dan Russel (1993) memberi batasan mengenai kinerja sebagai ".....the record of outcomes produced on speciefied job function or activity during a specified time priod."

Kinerja merupakan suatu prestasi atau tingkat keberhasilan yang dicapai oleh individu atau suatu organisasi dalam melaksanakan pekerjaan pada suatu periode tertentu. Menurut Stoner dalam Arnia (2001) kinerja (performance) merupakan kuantitas dan kualitas pekerjaan yang diselesaikan oleh individu, kelompok atau organisasi. Kinerja merupakan hasil yang dicapai oleh suatu fungsi kerja atau aktivitas selama periode tertentu yang dapat dicapai oleh seseorang atau sekelompok orang dalam suatu organisasi sesuai dengan wewenang dan tanggung jawab masing-masing dalam upaya mencapai tujuan organisasi yang bersangkutan secara legal,tidak melanggar hukum dan sesuai dengan moral dan etika.

Mathis dan Jackson (2002) menyatakan bahwa banyak faktor yang dapat mempengaruhi kinerja dari individu tenaga kerja yang meliputi, kemampuan mereka,

\footnotetext{
${ }^{1}$ Mahasiswa Program Magister Manajemen Pascasarjana Universitas Mataram

${ }^{2}$ Dosen Pembimbing Utama,Dosen Program Magister Manajemen Pascasarjana Universitas Mataram

${ }^{3}$ Dosen Pembimbing Pendamping, Dosen Program Magister Manajemen Pascasarjana Universitas Mataram
} 


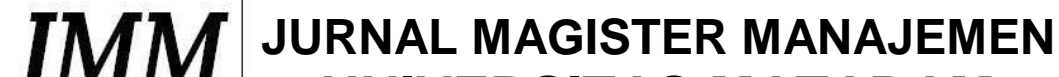 UNIVERSITAS MATARAM UNRAM VOL. 6 No. 1 MARET 2017}

motivasi, dukungan yang diterima, keberadaan pekerjaan yang mereka lakukan, dan hubungan mereka dengan organisasi. Pada banyak organisasi, kinerjanya lebih bergantung pada kinerja dari individu tenaga kerja. Secara lebih spesifik Anoraga (2004) menyatakan faktor-faktor yang dapat mempengaruhi kinerja karyawan terdiri dari: Motivasi, pendidikan, disiplin kerja, keterampilan, sikap etika kerja, gizi dan kesehatan, tingkat penghasilan, lingkungan dan sistem kerja, teknologi, sarana produksi, jaminan sosial, manajemen dan kesempatan berprestasi. Selanjutnya William Stern dalam Mangkunegara (2006) menyatakan bahwa faktor-faktor penentukinerja individu adalah faktor individu dan faktor lingkungan kerja organisasi yaitu.

Salah satu faktor yang mempengaruhi kinerja individu adalah komitmen organisasi yang merupakan sikap karyawan untuk tetap berada dalam organisasi dan terlibat dalam upaya-upaya mencapai misi,nilai-nilai dan tujuan organisasi. Komitmen merupakan suatu bentuk loyalitas yang lebih konkrit yang dapat dilihat dari sejauhmana karyawan mencurahkan perhatian, gagasan, dan tanggung jawab dalam upaya mencapai tujuan organisasi (Alwi : 2001).

Komitmen organisasi karyawan merupakan masalah penting, karena masalah mobilitas dan output yang dihasilkan karyawan sangat mempengaruhi langsung terhadap kualitas pelayanan. Karyawan yang memiliki komitmen organisasi yang kuat terhadap perusahaan atau organisasi serta memiliki loyalitas dalam bekerja akan berupaya untuk terus mengembangkan diri guna meningkatkan prestasi kerjanya. Komitmen organisasi menyiratkan hubungan karyawan dengan perusahaan atau organisasi secara aktif, Irefin (2014) dalam penelitiannya

Faktor lain yang mempengaruhi kinerja adalah motivasi, Motivasi mempersoalkan bagaimana cara mengarahkan daya dan potensi agar bekerja mencapai tujuan yang ditentukan (Hasibuan, 2006: 141). Pada dasarnya seorang bekerja karena keinginan memenuhi kebutuhan hidupnya. Dorongan keinginan pada diri seseorang dengan orang yang lain berbeda sehingga perilaku manusia cenderung beragam di dalam bekerja. Kemudian John P. Campbell, Counser, Schenk, Price, Smitph (2002) mengemukakan bahwa motivasi mencakup di dalamnya arah atau tujuan tingkah laku, kekuatan respons, dan kegigihan tingkah laku. Di samping itu, istilah tersebut mencakup sejumlah konsep dorongan (drive), kebutuhan (need), rangsangan (incentive), ganjaran (reward), penguatan (reinforcement), ketetapan tujuan (goal setting), harapan (expectancy), dan sebagainya.Hasil penelitian juga membuktikan adanya antara motivasi terhadap kinerja sebagai contoh Emeka (2015) dalam penelitiannya menunjukkan bahwa motivasi ekstrinsik diberikan kepada pekerja dalam suatu organisasimemiliki pengaruh yang signifikan terhadap kinerja pekerja.

Fenomena kinerja anggota yang dikaitkan dengan komitmen organisasional dengan motivasi kerja di temui pada organisasi Program Penanggulangan Kemiskinan di Perkotaan (PNPM) dilaksanakan sejak tahun 1999 sebagai suatu upaya pemerintah untuk membangun kemandirian masyarakat dan pemerintah daerah dalam menanggulangi kemiskinan secara berkelanjutan. Program ini sangat strategis karena menyiapkan landasan kemandirian masyarakat berupa lembaga kepemimpinan masyarakat yang representatif, mengakar dan kondusif bagi perkembangan modal sosial (socialcapital) masyarakat di masa mendatang serta 


\section{IMM JURNAL MAGISTER MANAJEMEN UNIVERSITAS MATARAM UNRAM VOL. 6 No. 1 MARET 2017}

menyiapkan program masyarakat jangka menengah dalam penanggulangan kemiskinan yang menjadi pengikat dalam kemitraan masyarakat dengan pemerintah daerah dan kelompok peduli setempat.

BKM merupakan lembaga swadaya masyarakat yang bertugas memberikan pelayanan kepada publik sesuai dengan fungsi lembaga tersebut. Dalam proses pelaksanaan kegiatan tersebut para anggota diharapkan memberikan pelayanan yang terbaik sesuai dengan standar pelayanan, namum ada beberapa faktor yang menyebabkan pelayanan yang diberikan tidak maksimal dikarenakan kinerja anggota masih rendah, hal ini terlihat dari seringnya anggota meninggalkan pekerjaannya, sehingga pelaksanaan pekerjaan yang seharusnya dilakukan menjadi terkendala. Bahkan sering terdapat pekerjaan yang tertundatunda yang diakibatkan anggota yang mengerjakan pekerjaan tersebut tidak berada di tempat kerjanya. Hal ini diduga karena kondisi kerja untuk melaksanakan pekerjaannya sehari-hari kurang mendukung, sehingga anggota lebih senang beradadi luar ruang kerjanya dan ada beberapa anggota yang lebih senang berada di luar unit kerjanya sendiri. Namun ada beberapa anggota yang sering meninggalkan pekerjaan yang seharusnya dilakukan, bukan dikarenakan kondisi kerjanya yang kurang baik saja, tetapi juga dikarenakan reward yang diperolehnya selama ini dirasa tidaklah memadai. Hal-hal tersebut di atasmenyebabkan fungsi lembaga sebagai pelayanan publik tidak berjalan dengan baik dikarenakan kinerja pegawai yang terus menurun. Program kerja yang tidak terlaksana sesuai jadwal yang telah direncanakan misalnya penyelesaian administrasi laporan kegiatan yang tertunda. Hal tersebut tidak lepas dari faktor komiten dan motivasi anggota Badan Keswadayaan Masyarakat yang kurang baik.

Dalam konteks organisasi BKM, pengukuran kinerja dilakukan untuk menilai seberapa baik BKM tersebut melakukan tugas pokok dan fungsi yang dilimpahkan kepadanya selama periode tertentu. Pengukuran kinerja BKM merupakan wujud dari vertical accountability yaitu pengevaluasian kinerja oleh anggota dan sebagai bahan horizontal accountability BKM yaitu kepada masayarakat atas amanah yang diberikan kepadanya. Komitmen organisasisional dalam hal ini berkaitan dengan bagaimana anggota BKM mengeluarkan sumber daya fisik, mental dan spiritual mereka, hal ini dapat dilihat dari rasa memiliki, kebanggan dan pengabdiannya serta bagaimana tanggung jawab anggota BKM untuk mencapai tujuan kinerja yang baik untuk organisasi BKM. Motivasi dalam organisasi BKM merupakan bagaimana melihat kemauan atau keinginan anggota BKM dalam bekerja, dengan motivasi kerja yang tinggi akan mempermudah menjalankan dan menyelesaikan tugas yang diberikan, selain itu anggota BKM harus bisa menunjukkan prestasi terhadap pekerjaan yang dilakukan. Dengan motivasi yang tinggi dan prestasi kerja yang baik dari anggota dapat mempermudah mencapai tujuan kinerja yang baik bagi organisasi.

Berdasarkan pemahaman teori dan hasil hasil penelitian serta penomena di atas maka dirasa perlu untuk melakukan penelitian tentang Pengaruh Komitmen Organisasisional dan Motivasi Kerja Terhadap Kinerja Anggota Badan Keswadayaan Masyarakat (BKM) Pada Program PNPM di Kota Mataram.

\section{LANDASAN TEORI}

\subsection{Kinerja}

Menurut Rivai dan Basri (2005) pengertian kinerja adalah kesediaan seseorang atau kelompok orang untuk melakukan sesuatu kegiatan dan menyempurnakannya sesuai dengan tanggung jawab dengan hasil seperti yang diharapkan. Menurut Tika (2006) kinerja sebagai hasil-hasil fungsi pekerjaan/kegiatan seseorang atau kelompok dalam suatu 


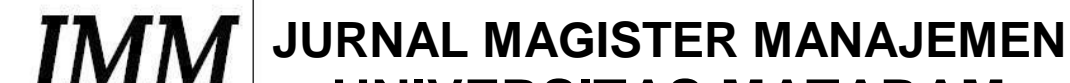 UNIVERSITAS MATARAM UNRAM VOL. 6 No. 1 MARET 2017}

organisasi yang dipengaruhi oleh berbagai faktor untuk mencapai tujuan organisasi dalam periode waktu tertentu.

Menurt Dessler (2000) ada tiga faktor dalam penilaian kinerja yang populer,yaitu:

1. Prestasi pekerjaan, meliputi: akurasi, ketelitian, keterampilan, dan penerimaan keluaran

2. Kuantitas pekerjaan, meliputi:volumekeluaran dan kontribusi

3. Kepemimpinan yang diperlukan, meliputi: membutuhkan saran, arahan atau perbaikan.

Sedangkan menurut Handoko (2002) menyebutkan bahwa penilaian kinerja terdiri dari 3 kriteria,yaitu

1. Penilaian berdasarkan hasilyaitu penilaian yang didasarkan adanya target-target dan ukurannya spesifik serta dapat diukur.

2. Penilaian berdasarkan perilaku yaitu penilaian perilaku-perilaku yang berkaitan dengan pekerjaan.

3. Penilaian berdasarkan judgement yaitu penilaian yang berdasarkan kualitas pekerjaan, kuantitas pekerjaan, koordinasi, pengetahuan pekerjaan dan keterampilan, kreativitas, semangat kerja, kepribadian, keramahan, intregitas pribadi serta kesadaran dan dapat dipercaya dalam menyelesaikan tugas.

Faktor-faktor yang dapat mempengaruhi kinerja menurut Gibson, at al,. (2008:134), adalah kemampuan dan keterampilan, demografi, persepsi, sikap, kepribadian, motivasi, komitmen organisasional, stres kerja, disiplin kerja, imbalan /kompensasi, kepemimpinan, konflik, kekuasaan, struktur organisasi, desain pekerjaan, desain organisasi, komunikasi, dan karir. Menurut Mangkunegara (2000) faktor yang mempengaruhi pencapaian kinerjayang baik adalah:1). Faktor Motivasi dimana, motivasi motivasi itumembentuk sikap (attitude) seorang karyawan dalam menghadapi situasikerja. Motivasi merupakan kondisi yang dapat menggerakan diri karyawan yang terarah kepada pencapaian tujuan organisasi; 2). Faktor Komitmen Organisasi, merupakan sikap tentang loyalitas karyawan kepada organisasi mereka, dan sebuah proses terus menerus berlanjut di mana partisipan organisasi mengungkapkan perhatian untuk organisasi dan kesuksesan yang berkelanjutan; 3). Faktor Kemampuan, dimana secara psikologis, kemampuan (ability) karyawan terdiri dari kemampuanpotensi (IQ) dan kemampuan reality (Knowledge+ skill). Artinya karyawan yangmemiliki IQ di atas rata-rata (IQ 110-120) dengan pendidikan yang memadai untuk jabatannya dan terampil dalam mengerjakan pekerjaan sehari-hari, maka ia akan lebih mudah mencapai kinerja yang diharapkan. Oleh sebab itu karyawan perlu ditempatkan pada pekerjaan yang sesuai dengan keahliannya.

\subsection{Komitmen Organisasional}

Komitmen organisasional dimaknai sebagai identifikasi, keterlibatan, dan loyalitas oleh pekerja terhadap organisasi atau unit organisasinya, yang ditunjukan dalam sikap penerimaan, keyakinan yang kuat terhadap nilai-nilai dan tujuan organisasi. Selain itu, komitmen organisasional ditunjukan oleh adanya dorongan yang kuat untuk mempertahankan keanggotaan dalam organisasi.

Greenberg dan Baron (1997 : 190) mendefinisikan komitmen organisasional adalah keberadaan seseorang mengidentifikasi dan terlibat dengan organisasinya dan tidak memiliki keinginan untuk meninggalkan organisasi tersebut.

Komitmen organisasional didefinisikan sebagai penghubung psikologi antara karyawan dan organisasinya (Meyer dan Allen, 1996 : 252-253). Sesuai dengan perspektif ini, hubungan psikologi antara karyawan dan organisasinya dapat memunculkan tiga komponen komitmen organisasi yaitu: affective, continuance dan normative(Meyer dan Allen, 1996).

\section{Komponen komitmen organisasional}




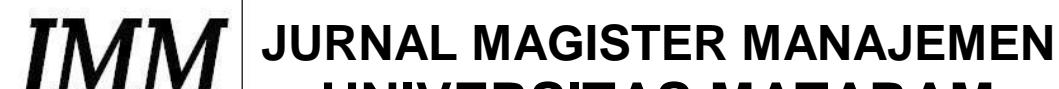 UNIVERSITAS MATARAM UNRAM VOL. 6 No. 1 MARET 2017}

1. Komitmen Affective

Meyer dan Allen yang dikutip oleh Brown dan Kristena (2002 : 3) mendefinisikan komitmen affective, yaitu komitmen yang dimiliki oleh karyawan dan nilai-nilai yang dimiliki oleh karyawan tersebut, sejalan dengan nilai-nilai yang dimiliki oleh organisasi, tempat dimana mereka bekerja, dan ditandai sebagai emosi psikologis karyawan terhadap organisasi. Meyer dan Allen (1993) yang dikutip oleh Brown (2003 : 101) mengemukakan beberapa unsur-unsur pengukuran komitmen qffective karyawan, antara lain:

1. Adanya kebahagiaan menghabiskan karir selama dalam organisasi.

2. Merasakan bahwa persoalan organisasi juga persoalan karyawan.

3. Mempunyai rasa memiliki yang kuat pada organisasi.

4. Merasa terikat secara emosional terhadap organisasi.

5. Merasa menjadi bagian keluarga organisasinya.

6. Merasakan bahwa organisasinya sangatlah berarti.

2. Komitmen Continuance

Meyer dan Allen, yang dikutip oleh Brown dan Kristena (2002:3), mengemukakan bahwa komitmen continuance adalah komitmen yang dimiliki seseorang karena pertimbangan-pertimbangan besar yang telah diinvestasikan (tenaga, pikiran dan waktu) apabila ia meninggalkan organisasinya, dan yang digambarkan sebagai suatu kebutuhan untuk tinggal pada organisasi. Meyer dan Allen, yang dikutip oleh Brown (2003:101), mengemukakan beberapa unsur-unsur pengukuran komitmen continuance karyawan, antara lain:

1. Merasa sangat sulit meninggalkan organisasi meskipun menginginkan.

2. Adanya keterbatasan alternatif pekerjaan lain yang tersedia.

3. Merasa tetap tinggal di dalam organisasi adalah suatu kebutuhan.

4. Adanya sedikit pilihan untuk dikorbankan apabila meninggalkan organisasi.

5. Merasa sudah banyak pengorbanan diri yang diberikan kepada organisasi.

6. Merasa banyak yang terganggu, apabila meninggalkan organisasi

3. Komitmen Normative

Meyer dan Allen yang dikutip oleh Brown dan Kristena (2002 : 3), mengatakan bahwa komitmen normative, merupakan komitmen yang dimiliki seorang karena orang tersebut merasa berkewajiban mengabdi kepada prestasinya, karyawan memiliki loyalitas atas manfaat pelatihan dan pendidikan yang telah diterima dari organisasinya. Loyalitas karyawan dinyatakan dengan cara dan bekerja pada organisasinya dan ditandai oleh kepercayaan karyawan. Meyer dan Allen dikutip oleh Brown (2002 : 101), juga mengemukakan beberapa unsur-unsur pengukuran komitmen normative karyawan, antara lain :

1. Adanya kewajiban untuk tetap bersama atasan

2. Merasakan tidak tepat meninggalkan organisasi, walaupun organisasi memberikan keuntungan

3. Merasa bersalah apabila meninggalkan organisasi

4. Loyal pada organisasi

5. Adanya suatu tanggung jawab yang tinggi terhadap orang-orang yang berada di dalam organisasi

6. Merasa berhutang budi pada organisasi

Indikator variabel komitmen dalam Ghany, ( 2007) adalah 1) Tanggungjawab dalam menyelesaikan tugas kolektif, 2) Bersedia melakukan perubahan atau perbaikan untuk terciptanya tata kelola pemerintah yang baik, 3) Mempunyai rasa peduli terhadap perubahan 


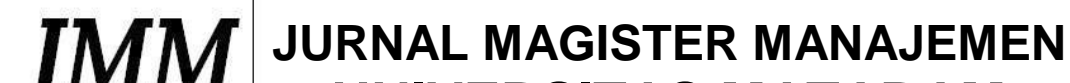 UNIVERSITAS MATARAM UNRAM VOL. 6 No. 1 MARET 2017}

regulasi, 4) Mempunyai loyalitas yang tinggi terhadap lembaga, 5) Bekerja dan mengabdi dengan sungguh-sungguh kepada lembaga, 6) Bersedia bekerjasama dengan baik bersama tim.

\subsection{Motivasi}

Nawawi (2005) mendefinisikan bahwa motivasi merupakan proses psikologis yang berlangsung dalam interaksi antar keperibadian yang berbeda-beda untuk memenuhi kebutuhan sebagai manusia. Mangkuprawira (2007) menjelaskan bahwa motivasi merupakan dorongan yang membuat karyawan melakukan sesuatu dengan cara dan untuk mencapai tujuan tertentu, motivasi itu timbul tidak saja karena ada unsur di dalam dirinya, tetapi juga kama adanya stimulus dari luar, seberapapun tingkat kemampuan yang dimiliki seseorang, pasti butuh motivasi. Robbins dan Judge (2007) mendefinisikan motivasi sebagai proses yang menjelaskan intensitas, arah dan kekuatan usaha untuk mencapai suatu tujuan.

\section{Teori Motivasi}

Secara garis besar, teori motivasi dikelompokan kedalam tiga kelompok yaitu teori motivasi dengan pendekatan isi (content theory), teori motivasi dengan pendekatan proses (process theory) dan teori motivasi dengan pendekatan penguat (reinforcement theory).Beberapa teori motivasi dijelaskan sebagai berikut:

1. Teori Motivasi Klasik (Motivation Clasic Theory)

Teori ini dikembangkanoleh Fredrick Winslow Taylor dalam Hasibuan (2005) yang menyatakan bahwa motivasi para Anggota itu hanya untuk dapat memenuhi keperluan dan kepuasan biologis saja. Sedangkan keperluan biologis itu sendiri adalah keperluan yang diperlukan untuk mempertahankan kelangsungan hidup seseorang.

2. Teori Hirarki Kebutuhan Maslow (Need Hierarchy Theory)

Teori ini dikembangkan oleh Abraham H. Maslow yang menyatakan bahwa motivasi kerja ditunjukkan untuk memenuhi kebutuhan dan kepuasan kerja baik secara biologis maupun psikologis baik yang berupa materi maupun non materi. Gibson (1996 : 189) menjelaskan bahwa teori motivasi yang dikembangkan oleh Abraham $\mathrm{H}$.

3. Teori ERG (Existence, Relatedness, Growth) Aldefer

Teori Aldefer dikenal dengan akronim Existence (Kebutuhan akan eksistensi), Relatedness ( Kebutuhan untuk berhubungan dengan pihak lain ), dan Growth ( Kebutuhan akan pertumbuhan). Gibson (1996 : 194) menjelaskan bahwa teori ERG merupakan refleksi dari tiga kebutuhan dasar, yaitu Extence needs : kebutuhan-kebutuhan terpuaskan oleh faktorfaktor seperti makan, minum, udara, air, pakaian, gaji, keamanan, kondisi kerja.

4. Teori Tiga Faktor (Theree Factors Theory) David Me Clelland

Mc. Clelland dalam Mangkuprawira (2007), mengengemukakan bahwa produktivitas seseorang sangat ditentukan oleh virus mental adalah kondisi jiwa yang mendorong seseorang untuk mampu mencapai prestasinya secara maksimal, virus mental yang diaksud terdiri dari tiga dorongan kebutuhan, yaitu Need For Achievement (kebutuhan untuk berprestasi), Need For Affiliation (kebutuhan untuk memperluas pergaulan) dan Need For Power (kebutuhan untuk menguasai sesuatu).

Faktor-Faktor yang Mempengaruhi Motivasi Kerja

Gouzaly (2000 : 257) mengelompokan faktor-faktor motivasi kedalam dua kelompok yaitu :

1. Faktor eksternal (karakteristik organisasi) yaitu lingkungan kerja yang menyenangkan, tingkat kompensasi, supervisi yang baik, adanya penghargaan atas prestasi, status dan tanggung jawab. 


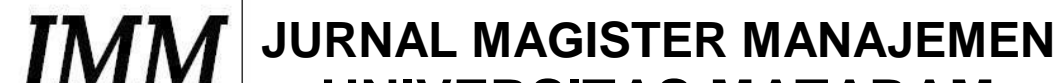 UNIVERSITAS MATARAM UNRAM VOL. 6 No. 1 MARET 2017}

2. Faktor internal (karakteristik pribadi) yaitu tingkat kematangan pribadi, tingkat pendidikan, keinginan dan harapan pribadi, kebutuhan, kelelahan dan kebosanan.

Indikator-Indikator Motivasi Kerja

Parrek, Udai dalam Mas'ud (2004) menjelaskan bahwa indikator motivasi kerja yang dapat mengukur kebutuhan (pendorong) motivasi seseorang di tempat kerja terdiri dari :

1. Prestasi kerja.

2. Pengaruh.

3. Pengendalian.

4. Ketergantungan.

5. Perluasan.

6. Afiliasi.

2.3. Kerangka Konseptual dan Pengembangan Hipotesis

2.3.1. Pengaruh Komitmen Organisasional Terhadap Kinerja

Menurut Simandjuntak (2005), komitmen adalah kesanggupan untuk bertanggung jawab terhadap hal-hal yang di percayakan kepada seseorang. Komitmen tidak ada hubungannya sama sekali dengan bakat, Kepintaran atau talenta. Dengan komitmen yang kuat akan memungkinkan seseorang bisa mengeluarkan sumber daya fisik, mental dan spiritual tambahan yang bisa di peroleh, sebaliknya tanpa komitmen maka pekerjaan-pekerjaan besar akan sulit terlaksana.

Sebagai salah satu yang mempengaruhi kinerja komitmen organisasi merupakan sikap karyawan untuk tetap berada dalam organisasi dan terlibat dalam upaya-upaya mencapai misi, nilai-nilai dan tujuan organisasi. Komitmen merupakan suatu bentuk loyalitas yang lebih konkrit yang dapat dilihat dari sejauh mana karyawan mencurahkan perhatian, gagasan, dan tanggung jawab dalam upaya mencapai tujuan organisasi (Alwi : 2001).

Komitmen organisasi menyiratkan hubungan karyawan dengan perusahaan atau organisasi secara aktif, Irefin (2014) dalam penelitiannya membahas Pengaruh Komitmen Karyawan Terhadap Kinerja Organisasi, memperlihatkan bahwa hubungan yang cukup kuat antara komitmen karyawan dan kinerja organisasi; Ada juga hubungan yang sangat kuat antara komitmen karyawan dan omset karyawan, beberapa rekomendasi yang dibuat adalah bahwa: Manajemen harus mempekerjakan karyawan yang cenderung terkait dengan organisasi; Manajemen harus membuat tugas yang jelas dan realistis dan preview organisasi.

Komitmen organisasisional dalam hal ini berkaitan dengan bagaimana anggota BKM mengeluarkan sumber daya fisik, mental dan spiritual mereka, hal ini dapat dilihat dari rasa memiliki, kebanggan dan pengabdiannya serta bagaimana tanggung jawab anggota BKM untuk mencapai tujuan kinerja yang baik untuk organisasi BKM.

Berdasarkan landasan teoritis dan kajian empiris yang telah diuraikan di atas dapat diajukan perumusan hipotesis :

H1: Komitmen organisasional mempunyai pengaruh secara parsial terhadap kinerja anggota BKM

2.3.2. Pengaruh Motivasi Terhadap Kinerja

Istilah motivasi berasal dari kata Latin "movere" yang berarti dorongan atau menggerakkan. Motivasi mempersoalkan bagaimana cara mengarahkan daya dan potensi agar bekerja mencapai tujuan yang ditentukan (Hasibuan, 2006: 141). Pada dasarnya seorang bekerja karena keinginan memenuhi kebutuhan hidupnya. 


\section{TMM JURNAL MAGISTER MANAJEMEN UNIVERSITAS MATARAM UNRAM VOL. 6 No. 1 MARET 2017}

Dorongan keinginan pada diri seseorang dengan orang yang lain berbeda sehingga perilaku manusia cenderung beragam di dalam bekerja.

Salah satu faktor yang mempengaruhi kinerja adalah motivasi, apabila setiap orang dalam suatu organisasi merasakan bahwa prinsip yang mendasari tindakan dan perilaku sesuai dengan pandangan hidupnya, tidak menyimpang dari prinsip pribadinya, ia akan bekerja dengan baik. Apabila mereka merasakan bahwa pandangan hidupnya, cita-citanya akan mendapat tempat yang sesuai di dalam suatu organisasi di mana dia bekerja, juga dapat memahami maksud, tujuan dan ruang lingkup kegiatan dalam perusahaan, maka mereka akan selalu terdorong untuk bekerja lebih baik, karena menyadari bahwa apa yang bermanfaat bagi organisasi juga bermanfaat bagi dirinya. Apa yang didambakan bagi masa depannya dapat dipenuhi oleh organisasi di mana dia bekerja, sehingga akan merasakan kepuasan dalam bekerja dan akhirnya akan berdampak pada peningkatan kinerja.

Emeka (2015) dalam penelitiannya menunjukkan bahwa motivasi ekstrinsik diberikan kepada pekerja dalam suatu organisasimemiliki pengaruh yang signifikan terhadap kinerja pekerja.

Motivasi dalam organisasi BKM merupakan bagaimana melihat kemauan atau keinginan anggota BKM dalam bekerja, dengan motivasi kerja yang tinggi akan mempermudah menjalankan dan menyelesaikan tugas yang diberikan, selain itu anggota BKM harus bisa menunjukkan prestasi terhadap pekerjaan yang dilakukan. Dengan motivasi yang tinggi dan prestasi kerja yang baik dari anggota dapat mempermudah mencapai tujuan kinerja yang baik bagi organisasi.

Berdasarkan landasan teoritis dan kajian empiris yang telah diuraikan di atas dapat diajukan perumusan hipotesis :

H2 : Motivasi mempunyai pengaruh secara parsial terhadap kinerja anggota BKM

2.3.3. Pengaruh Komitmen organisasional dan Motivasi Secara Simultan Terhadap Kinerja

Ida Respatiningsih (2015) Tujuan penelitian yaitu untuk menganalisis pengaruh komitmen organisasi, motivasi, kapabilitas dan kepuasan kerja terhadap kinerja pegawai. Metode analisis data yang digunakan analisis kuantitatif menggunakan statistik inferensial dengan regresi linier sebagai pengujian hipotesisnya. Hasil penelitian menemukan (1) secara parsial (individu) terdapat pengaruh yang positif dan signifikan antara komitmen organisasi terhadap kinerja pegawai; (2) secara parsial (individu) terdapat pengaruh yang positif dan signifikan antara motivasi terhadap kinerja pegawai; (3) secara parsial (individu) terdapat pengaruh yang positif dan signifikan antara kapabilitas terhadap kinerja pegawai; dan (4) secara parsial (individu) terdapat pengaruh yang positif dan signifikan antara kepuasan kerja terhadap kinerja pegawai.Dan secara simultan komitmen organisasi, motivasi, kapabilitas dan kepuasan kerja berpengaruh terhadap kinerja pegawai.

Fitrie (2008) dalam penelitiannya bertujuan untuk mengetahui pengaruh kualitas SDM, motivasi, sarana pendukung dan komitmen organisasi terhadap kinerja SKPD di Provinsi Jambi. Model alat analisis yang digunakan adalah regresi linier berganda dengan hasil penelitian menemukan bahwa kualitas SDM,motivasi, sarana pendukung dan komitmen organisasi

berpengaruh positif secara signifikan terhadap kinerja SKPD di Provinsi Jambi. 


\section{TMM JURNAL MAGISTER MANAJEMEN UNIVERSITAS MATARAM UNRAM VOL. 6 No. 1 MARET 2017}

Berdasarkan kajian empiris yang telah diuraikan di atas dapat diajukan perumusan hipotesis :

H3 : Komitmen organisasi dan motivasi mempunyai pengaruh secara simultan terhadap kinerja anggota BKM

2.3.4. Pengaruh Dominan Terhadap Kinerja

Motivasi seorang berawal dari kebutuhan, keinginan dan dorongan untuk bertindak demi tercapainya kebutuhan atau tujuan. Hal ini menandakan seberapa kuat dorongan, usaha, intensitas, dankesediaannya untuk berkorban demi tercapainya tujuan. Dalam hal ini semakinkuat dorongan atau motivasi dan semangat akan semakin tinggi kinerjanya. Mangkunegara (2005:67) menyatakan faktor yang mempengaruhi kinerja adalah faktor kemampuan dan faktor motivasi. Sementara Mathis (2007:84) menyatakan kinerja yang dicari oleh perusahaan dari seseorang tergantung dari kemampuan, motivasi, dan dukungan individu yang diterima. Hasil penelitian inikonsisten dengan penelitian Emeka (2015), Nizam (2015) dan Muogbo (2013) yang menyatakan bahwa motivasi berpengaruh sifnifikan terhadap kinerja karyawan.

Berdasarkan kajian empiris yang telah diuraikan di atas dapat diajukan perumusan hipotesis :

H3 : Motivasi mempunyai pengaruh dominan terhadap kinerja anggota BKM

Gambar 4.1

Karangka Konseptual

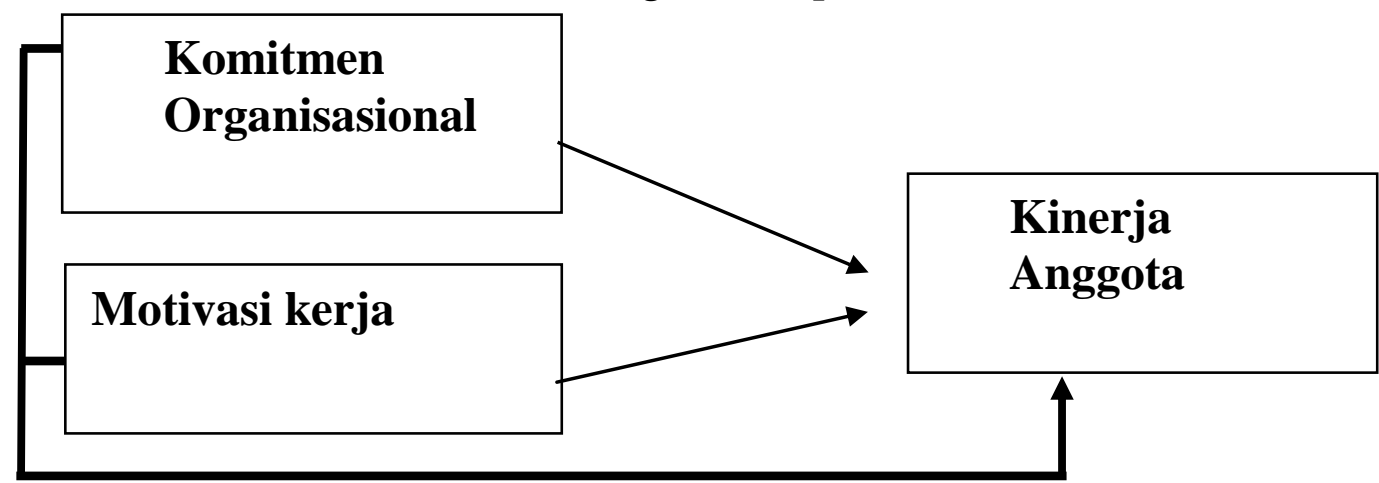

Keterangan :

Pengaruh secara parsial

Pengaruh secara simultan 


\section{TMM JURNAL MAGISTER MANAJEMEN UNIVERSITAS MATARAM UNRAM VOL. 6 No. 1 MARET 2017}

\section{METODE PENELITIAN}

Jenis penelitian yang digunakan dalam penelitian ini adalah penelitian asosiatif. Menurut Sugiyono ( 2006:11 ) penelitian asosiatif adalah jenis penelitian yang bertujuan untuk mengetahui pengaruh suatu variabel terhadap variabel lainnya. Pada penelitian ini akan dikaji pengaruh dari komitmen organisasional dan motivasi kerja terhadap kinerja Anggota Badan Keswadayaan Masyarakat (BKM) pada program PNPM Mandiri Perkotaan Kota Mataram.

Populasi dalam penelitian ini berjumlah 556 merupakan Anggota Badan Keswadayaan Masyarakat (BKM) pada program PNPM Mandiri Perkotaan Kota Mataram yang tersebar pada berbagai bidang pekerjaan pada lingkup Badan Keswadayaan Masyarakat (BKM) pada program PNPM Mandiri Perkotaan kota Mataram. Teknik Sampel yang digunakan adalah proportonate random sampling dengan jumlah sampel sebanyak 85 orang,

Analisis regresi linier berganda digunakan untuk mengetahui ada tidaknya pengaruh komitmen organisasional, motivasi kerja terhadap kinerja Anggota pada Badan Keswadayaan Masyarakat (BKM) pada program PNPM Mandiri Perkotaan Kota Mataram. Untuk hal tersebut digunakan alat analisis statistik yaitu analisis regresi linear berganda pada program SPSS. Versi 16. For Windows. Adapun formulasi dari regresi linear berganda adalah sebagai berikut:

$Y=b_{0}+b_{1} X_{1}+b_{2} X_{2}+e$

Dimana :

$$
\begin{array}{ll}
\mathrm{Y} & =\text { Kinerja Anggota } \\
\mathrm{b}_{0} & =\text { Konstanta } \\
\mathrm{b}_{1} & =\text { Koefisien regresi komitmen organisasional } \\
\mathrm{b}_{2} & =\text { Koefisien motivasi kerja } \\
\mathrm{X}_{1} & =\text { Komitmen organisasional } \\
\mathrm{X}_{2} & =\text { Motivasi kerja } \\
\mathrm{e} & =\text { kesalahan pengganggu }
\end{array}
$$

\section{PEMBAHASAN}

\subsection{Deskripsi Variabel Penelitian}

\subsubsection{Deskripsi Variabel Komitmen Organisasi $\left(X_{1}\right)$}

Komitmen organisasional dalam penelitian ini adalah persepsi Anggota mengenai keinginan, kebutuhan, dan keharusan terhadap Badan Keswadayaan Masyarakat (BKM) pada program PNPM Mandiri Perkotaan Kota Mataram sebagai organisasi tempat mereka bekerja, tanggapan dari 85 responden mengkategorikan cukup tinggi terhadap indicator komitmen organisasional $\left(\mathrm{X}_{1}\right)$ yaitu:komitmen affective, komitmen continuance, dan komitmen normative dengan nilai mean yaitu 2,89 yang berarti sebagian besar anggota Badan Keswadayaan Masyarakat (BKM) pada program PNPM Mandiri Perkotaan Kota Mataram sudah cukup tinggi di dalam menjalankan peranannya sebagai pelaksana program tersebut maka peneliti menggunakan 18 indikator Komitmen organisasional(X1), Dimana dari 85 responden dari anggota Badan Keswadayaan Masyarakat (BKM) pada program PNPM Mandiri Perkotaan Kota Mataram untuk indikator-indikator komitmen organisasional tersebut adalah cukup tinggi.

\subsubsection{DeskripsiMotivasi Kerja(X2)}




\section{TMM JURNAL MAGISTER MANAJEMEN UNIVERSITAS MATARAM UNRAM VOL. 6 No. 1 MARET 2017}

Motivasi Kerja dalam penelitian ini adalah persepsi Anggota terhadap motif mereka sehingga mau melaksanakan suatu pekerjaan selama bekerja di Badan Keswadayaan Masyarakat (BKM) pada program PNPM Mandiri Perkotaan kota Mataram, untuk mengetahui ketepatan penempatan anggota BKM peneliti menggunakan 30 indikator Motivasi Kerja(X2). Dimana dari 85 responden dari anggota Badan Keswadayaan Masyarakat (BKM) pada program PNPM Mandiri Perkotaan Kota Mataram untuk indikator-indikator Motivasi kerja tersebut adalah cukup tinggi. Artinya keseluruhan indikator motivasi kerja yaitu:Prestasi kerja, pengaruh, pengendalian, ketergantungan, perluasan dan afiliasi menjadi pendorong mereka dalam bekerja di PNPM Mandiri Perkotaan Kota Mataram dalam mengelola BKM.

\subsubsection{Deskripsi Variabel Terikat Kinerja Anggota( $(\mathrm{Y})$}

Kinerja Anggotadalam penelitian ini adalah merupakan penilaian atasan terhadap hasil kerja yang dapat dicapai oleh Anggota Badan Keswadayaan Masyarakat (BKM) pada program PNPM Mandiri Perkotaan Kota Mataram sesuai dengan wewenang dan tanggung jawab masing-masing dalam rangka upaya mencapai tujuan organisasi, peneliti melihat 9 indikator kepuasan kerja(Y). Dari 85 responden anggota Badan Keswadayaan Masyarakat (BKM) pada program PNPM Mandiri Perkotaan Kota Mataram menunjukan kondisi kinerja sangat tinggi

\subsection{Pengujian Hipotesis}

1. Uji Hipotesa 1

Hipotesa 1 menyatakan bahwa komitmen organisasional (X1),motivasi kerja kerja (X2),secara bersama-sama berpengaruh signifikan terhadap kinerja anggota (Y)Badan Keswadayaan Masyarakat (BKM) pada program PNPM Mandiri Perkotaan Kota Mataram terbukti. Hal ini dilihat berdasarkan hasil pengolahan data yang ditampilkan pada tabel 4.13, dimana secara simultan dapat dilihat dari nilai fhitung $>\mathrm{ftabel}($ fhitung49,128) $>$ (ftabel dengan $0,05=2,710$, sumber ftabel pada lampiran) atau tingkat signifikan $<0,05$. Sehingga bisa dikatakan bahwa model regresi bisa digunakan untuk memprediksi kinerja anggota, atau dengan kata lain variabel komitmen organisasional (X1), motivasi kerja kerja (X2)secara bersama-sama berpengaruh signifikan terhadapkinerja anggota.

Tabel 1

Hasil Uji Secara Simultan Pengaruh Komitmen organisasional (X1), Motivasi Kerja(X2), Terhadap Kinerja Anggota (Y)

\begin{tabular}{|l|c|c|c|c|c|}
\hline \multicolumn{1}{|c|}{ Model } & $\mathbf{R}$ & $\begin{array}{c}\mathbf{R} \\
\text { Square }\end{array}$ & $\begin{array}{c}\text { Adjusted } \\
\text { R Square }\end{array}$ & F & Sig \\
\hline $\begin{array}{l}\text { KOMITMEN } \\
\text { ORGANISASIONAL }(X 1) \\
\text { MOTIVASI KRJA }(X 2)\end{array}$ & $0,738^{\mathrm{a}}$ & 0,545 & 0,534 & 49,128 & 0,000 \\
\hline
\end{tabular}

a. Predictors: (Constant), KOMITMEN ORGANISASIONAL, MOTIVASI KRJA

b. Dependent Variable: KINERJA ANGGOTA

Sumber. Pengolahan data lampiran 


\section{TMM JURNAL MAGISTER MANAJEMEN UNIVERSITAS MATARAM UNRAM VOL. 6 No. 1 MARET 2017}

Sedangkan hasil pengolahan dengan menggunakan program SPSS pada tebel 1, menunjukkan bahwa $R^{2}$ Square (koefisien determinasi) untuk model ini adalah 0,545 ini berarti 54,5\% kinerja anggota dapat dijelaskan oleh komitmen organisasional, motivasi kerja kerja, sedangkan sisanya $(100-54,5)=45,50 \%)$ dijelaskan oleh sebab-sebab lainnya.

\section{Uji Hipotesisis 2 dan Hipotesisis 3}

Pembuktian hipotesa 2 menyatakan bahwa komitmen organisasional berpengaruh signifikan terhadap kinerja anggota Badan Keswadayaan Masyarakat (BKM) pada program PNPM Mandiri Perkotaan Kota Mataram dan Hipotesa 3 yang menyatakan bahwa motivasi kerja berpengaruh signifikan terhadap kinerja anggota Badan Keswadayaan Masyarakat (BKM) pada program PNPM Mandiri Perkotaan Kota Mataram dapat di lihat dari hasil perhitungan regresi koefisien secara parsial dengan melihat nilai thitung dan tingkat signifakansinya dari variabel komitmen organisasional dan motivasi kerja terhadap kinerja anggota Badan Keswadayaan Masyarakat (BKM) sebagaimana terlihat pada tabel 2 berikut ini;

Tabel 2

Hasil Uji Koefisien $t_{\text {tes }}$ Regresi Komitmen Organisasional dan Motivasi Kerja Terhadap Kinerja Anggota

\begin{tabular}{|c|c|c|c|c|c|c|}
\hline & \multirow[t]{2}{*}{ Model } & \multicolumn{2}{|c|}{$\begin{array}{c}\text { Unstandardized } \\
\text { Coefficients }\end{array}$} & \multirow{2}{*}{$\begin{array}{c}\begin{array}{c}\text { Standardized } \\
\text { Coefficients }\end{array} \\
\text { Beta }\end{array}$} & \multirow{2}{*}{$\mathbf{t}_{\text {hitung }}$} & \multirow[t]{2}{*}{ Sig } \\
\hline & & B & Std. Error & & & \\
\hline \multirow{4}{*}{1} & (Constant) & .808 & .317 & & 2.550 & .013 \\
\hline & KOMITMEN & .354 & .082 & .344 & 4.347 & .000 \\
\hline & URGANISASIUNA & & & & & \\
\hline & MOTIVASI KERJA & .467 & .068 & .546 & 6.900 & .000 \\
\hline
\end{tabular}

a. Dependent Variable: KINERJA ORGANISASI

Sumber: Pengolahan data lampiran

berdasarkan pada table 4.14 tersebut, maka persamaan regresi linier bergandanya, sebagai berikut:

$\mathrm{Y}=\mathrm{bo}+\mathrm{b}_{1} \mathbf{X} 1+\mathrm{b}_{2} \mathrm{X} 2+\mathrm{e}$

$Y=0,808+0,354 X_{1}+0,467 X_{2}+e$

Dimana :

$\mathrm{Y}=$ KinerjaAnggota, $\mathrm{b}_{0}=$ Konstanta, $\mathrm{b}_{1}=$ Koefisien komitmen organisasional, $\mathrm{b}_{2}$

$=$ Koefisien motivasi kerja, $\mathrm{X}_{1}=$ Komitmen organisasional, $\mathrm{X}_{2}=$ Motivasi kerja, e

$=$ kesalahan pengganggu

Hasil perhitungan regresi linier berganda secara partial untuk membuktikan hipotesis 2 dan 3 pada tabel 2 tersebut dapat dijelaskan sebagai berikut:

1)

2) Nilai koefisien regresi variabel komitmen organisasional (X1)adalah sebesar 0,354 Artinya setiap perubahan yang terjadi pada komitmen organisasional (X1)akan menyebabkan perubahan pada kinerja anggota $(\mathrm{Y})$ sebesar 0,354 dengan asumsi variabel lainnya tetap. Koefisien regresi yang bertanda positif menunjukkan pengaruh yang searah antara komitmen organisasional (X1) dengan kinerja anggota $(\mathrm{Y})$. Nilai signifikan pada komitmen organisasional (X1) sebesar 0,000. Nilai ini lebih kecil dari nilai signifikansi yang telah ditentukan sebesar $5 \%(0,05)$ maka dapat disimpulkan bahwa 


\section{TMM JURNAL MAGISTER MANAJEMEN UNIVERSITAS MATARAM UNRAM VOL. 6 No. 1 MARET 2017}

komitmen organisasional (X1) berpengaruh signifikan secara partial terhadap kinerja $\operatorname{anggota}(Y)$.

3) Nilai koefisien regresi variabel motivasi kerja (X2)adalah sebesar 0,467. Artinya jika variabel motivasi kerja $(\mathrm{X} 2)$ berubah satu satuan, maka kinerja anggota $(\mathrm{Y})$ akan berubah sebesar 0,467 dengan asumsi variabel lainnya tetap. Koefisien regresi yang bertanda positif menunjukkan pengaruh yang searah antara variabel motivasi kerja(X2)dengan kinerja anggota $(\mathrm{Y})$, artinya apabila variabel motivasi kerja $(\mathrm{X} 2)$ meningkat maka kinerja anggota $(\mathrm{Y})$ akan meningkat dan sebaliknya. Nilai signifikan pada variabel $\mathrm{X} 2$ sebesar 0,000 . Nilai ini lebih besar dari nilai signifikansi yang telah ditentukan sebesar $5 \%(0,05)$ maka dapat disimpulkan bahwa variabel motivasi kerja(X2)berpengaruh signifikan secara parsial terhadap variabel kinerja anggota( $(Y)$.

\section{Uji Hipotesis 4}

Hipotesis 4 menyatakan motivasi kerja berpengaruh dominan terhadap kinerja anggota Badan Keswadayaan Masyarakat (BKM) pada program PNPM Mandiri Perkotaan Kota Mataram dapat diterima. Untuk membuktikan hipotesis 4 dapat dilihat dari hasil perhitungan koefisien determinasi $\left(\mathrm{r}^{2}\right)$ parsial, yaitu apabila nilai $\left(\mathrm{r}^{2}\right)$ parsial semakin besar, berarti semakin dominan pengaruh variabel bebas terhadap variabel terikat. Untuk variable motivasi kerja memiliki nilai tertinggi $\left(\mathrm{r}^{2}\right)$ dari variable komitmen organisasional yaitu 0,606. Untuk lebih jelasnya dapat dilihat pada tabel 4 berikut:

Tabel 4

Hasil Uji Determinasi ( $\left.\mathbf{r}^{2}\right)$ Parsial Komitmen Organisasional dan Motivasi Kerja Terhadap Kinerja Anggota

\begin{tabular}{|c|c|c|c|c|c|c|c|c|}
\hline & \multirow{2}{*}{ Model } & \multicolumn{2}{|c|}{$\begin{array}{l}\text { Unstandardized } \\
\text { Coefficients }\end{array}$} & \multirow{2}{*}{$\mathbf{t}$} & \multirow{2}{*}{ Sig. } & \multicolumn{3}{|c|}{ Correlations } \\
\hline & & B & $\begin{array}{l}\text { Std. } \\
\text { Error }\end{array}$ & & & $\begin{array}{l}\text { Zero- } \\
\text { order }\end{array}$ & Partial & Part \\
\hline \multirow{4}{*}{1} & (Constant) & .808 & .317 & 2.550 & .013 & & & \\
\hline & KOMITMEN & .354 & .082 & 4.347 & .000 & .530 & .433 & .324 \\
\hline & $\begin{array}{l}\text { ORGANISASIONA } \\
\text { L }\end{array}$ & & & & & & & \\
\hline & MOTIVASI KERJA & .467 & .068 & 6.900 & .000 & .664 & .606 & .514 \\
\hline
\end{tabular}

a. Dependent Variable: KINERJA ANGGOTA

Sumber: Pengolahan data lampiran

Berdasarkan hasil analisis pengujian hipotesis, dapat dibuat ringkasan hipotesis yang diterima, seperti yangdapat dilihat pada tabel 5 berikut: 


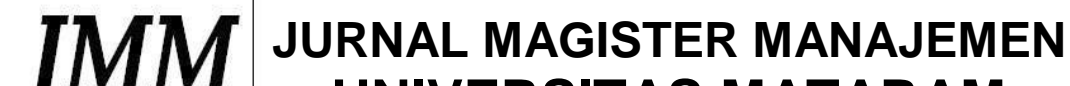 UNIVERSITAS MATARAM UNRAM VOL. 6 No. 1 MARET 2017}

Table 5 : Ringkasan Pengujian Hipotesis

\begin{tabular}{|c|c|c|c|}
\hline Hipotesis & Pernyataan Hipotesis & $\operatorname{Sig}(p)$ & Keputusan \\
\hline 1 & $\begin{array}{l}\text { Komitmen organisasional dan } \\
\text { motivasi kerja berpengaruh signifikan } \\
\text { secara simultan terhadap kinerja } \\
\text { anggota Badan Keswadayaan } \\
\text { Masyarakat (BKM) pada program } \\
\text { PNPM Mandiri Perkotaan Kota } \\
\text { Mataram }\end{array}$ & 0,000 & Diterima \\
\hline 2 & $\begin{array}{l}\text { Komitmen organisasional } \\
\text { berpengaruh signifikan terhadap } \\
\text { kinerja anggota Badan Keswadayaan } \\
\text { Masyarakat (BKM) pada program } \\
\text { PNPM Mandiri Perkotaan Kota } \\
\text { Mataram }\end{array}$ & 0.000 & Diterima \\
\hline 3 & $\begin{array}{l}\text { Motivasi kerja berpengaruh signifikan } \\
\text { terhadap kinerja anggota Badan } \\
\text { Keswadayaan Masyarakat (BKM) } \\
\text { pada program PNPM Mandiri } \\
\text { Perkotaan Kota Mataram }\end{array}$ & 0,000 & Diterima \\
\hline 4 & $\begin{array}{l}\text { Motivasi kerja berpengaruh dominan } \\
\text { terhadap kinerja anggota Badan } \\
\text { Keswadayaan Masyarakat (BKM) } \\
\text { pada program PNPM Mandiri } \\
\text { Perkotaan Kota Mataram }\end{array}$ & $0.606\left(\mathrm{r}^{2}\right)$ & Diterima \\
\hline
\end{tabular}

4.3. Pembahasan Hasil Penelitian

4.3.1. Pengaruh Komitmen Organisasional dan Motivasi KerjaSecara Simultan Terhadap Kinerja Anggota

Dari hasil analisis diketahui jika variabel komitmen organisasional dan motivasi kerja secara bersama-sama berpengaruh secara positif dan signifikan terhadap anggota Badan Keswadayaan Masyarakat (BKM), hal ini dapat dibuktikan dengan melihat hasil uji $\mathrm{F}$, dimana $\mathrm{F}_{\text {(Hitung) }}>\mathrm{F}_{\text {(Tabel). }}$. Hal ini menandakan bahwa anggota Badan Keswadayaan Masyarakat (BKM) pada program PNPM Mandiri Perkotaan Kota Mataram memberikan respon yang positif terhadap komitmen organisasional dan motivasi kerja, dalam arti mereka mengedepankan aspek keduanya dalam bekerja sehingga kinerja mereka dalam melaksanakan tugas semakin baik. Hal ini sesuai dengan teori-teori yang disebutkan pada pengaruh komitmen organisasionaldan motivasi kerja terhadap kinerja anggota Badan Keswadayaan Masyarakat (BKM) .

\subsubsection{Pengaruh Komitmen Organisasional Terhadap Kinerja Anggota.}

Secara statistik, variabel komitmen organisasioanl berpengaruh positif dan signifikan terhadap variabel kinerja anggota Badan Keswadayaan Masyarakat (BKM) pada program PNPM Mandiri Perkotaan Kota Mataram. Hal ini dibuktikan dengan nilai sigt lebih kecil dari 0,05 (nilai thitung lebih besar dari t tabel), dan nilai beta yang 


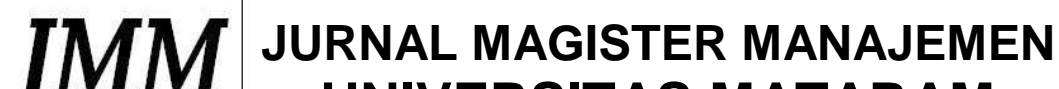 UNIVERSITAS MATARAM UNRAM VOL. 6 No. 1 MARET 2017}

positif menandakan bahwa komitmen organisasional mempunyai pengaruh yang searah terhadap kinerja anggota.

Munculnya komitmen organisasioanl anggota Badan Keswadayaan Masyarakat (BKM) pada program PNPM Mandiri Perkotaan Kota Mataram menunjukan identifikasi, keterlibatan, dan loyalitas oleh anggota Badan Keswadayaan Masyarakat (BKM) terhadap organisasi atau unit organisasinya, yang ditunjukan dalam sikap penerimaan, keyakinan yang kuat terhadap nilai-nilai dan tujuan program PNPM Mandiri Perkotaan Kota Mataram. Selain itu, komitmen organisasional anggota Badan Keswadayaan Masyarakat (BKM) ditunjukan oleh adanya dorongan yang kuat untuk mempertahankan keanggotaan dalam PNPM Mandiri Perkotaan Kota Mataram.

Dengan kata lain tiga komponen komitmen organisasional yaitu: affective, continuance dan normative tersebut dapat memunculkan pola terpadu prilaku anggota Badan Keswadayaan Masyarakat (BKM) termasuk pemikiran-pemikiran, tindakantindakan, pembicaraan-pembicaraan yang dapat meningkatkan komitmen organisasional anggota bagi Badan Keswadayaan Masyarakat (BKM). Semakin tinggi komitmen organisasional anggota, pada akhirnya akan menopang kinerja anggota Badan Keswadayaan Masyarakat (BKM).

Hasil penelitian yang dilakukan pada anggota Keswadayaan Masyarakat (BKM) pada program PNPM Mandiri Perkotaan Kota Mataram sejalan dengan pendapat para ahli seperti:(Christina T.S, 2012) mengatakan bahwa komitmen dapat tercapai apabila individu dalam organisasi sadar akan hak dan kewajibannya dalam organisasi tanpa melihat jabatan dan kedudukan masing-masing individu, karena pencapaian tujuan organisasi merupakan hasil kerja semua anggota organisasi yang bersifat kolektif. Sedangkan menurut Streers dalam Sopiah (2008) karyawan yang berkomitmen rendahakan berdampak pada turnover, tingginya absensi, meningkatnya kelambatan kerja dan kurangnya intensitas untuk bertahan sebagai karyawan diorganisasi tersebut, rendahnya kualitas kerja dan kurangnya loyalitas pada perusahaan. Near dan Jansen,dalam sopiah (2008) menambahkan bahwa bila komitmen karyawan rendah maka dia bisa memicu perilaku karyawan yang kurang baik, misalnya tindakan kerusuhan yang dampak lebih lanjutnya adalah reputasi organisasi menurun, kehilangan kepercayaan dari klien dan dampak yang lebih jauh lagi adalah menurunnya laba perusahaan. Komitmen terbagi menjadi tiga yaitu komitmen afektif,normatif,dan berkelanjutan. Apabila karyawan memiliki komitmen afektif yang tinggi maka karyawan akan cenderung tetap bekerja di perusahaan dan juga akan berpengaruh positif terhadap kinerja karyawan, dan mereka akan suka melakukan kerja tambahan untuk perusahaan, mereka akan mau memberikan saransaran bagi perbaikan dan kemajuan perusahaan. Para karyawan yang memiliki komitmen kontinyu

yang kuat dikarenakan mereka harus tinggal bersama organisasi (because theyhaveto). Dan para karyawan yang memiliki komitmen normative yang kuat dikarenakan mereka merasa bahwa mereka harus tinggal bersama (becausetheyfellthatthey have to).

Dari penjelasan tersebut dapat disimpulkan, bahwa jika seluruh anggota Badan Keswadayaan Masyarakat (BKM) pada program PNPM Mandiri Perkotaan Kota Mataram memiliki komitmen organisasional yang tinggi akan mempunyai pengaruh terhadap peningkatan kinerja anggota Badan Keswadayaan Masyarakat (BKM). Begitu pula sebaliknya jika komitmen organisasional rendah akan berpengaruh terhadap rendahnya kinerja anggota Badan Keswadayaan Masyarakat (BKM). 


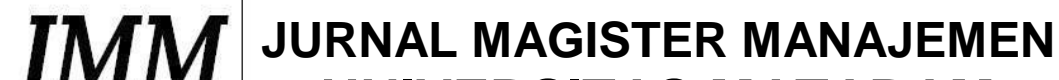 UNIVERSITAS MATARAM UNRAM VOL. 6 No. 1 MARET 2017}

\subsubsection{Pengaruh Motivasi Kerja Secara Partial Terhadap Kinerja Anggota.}

Dari hasil analisis diketahui jika variabel motivasi kerja Badan Keswadayaan Masyarakat (BKM)berpengaruh positif dan signifikan terhadap kinerja anggota Badan Keswadayaan Masyarakat (BKM), hal ini dibuktikan dengan nilai sig t yang lebih kecil dari 0,05 dan nilai $t$ hitung yang lebih besar dari nilai $t$ tabel. Nilai beta yang positif menandakan bahwa motivasi kerja anggota mempunyai pengaruh yang searah terhadap kinerja anggota Badan Keswadayaan Masyarakat (BKM).

Arti dari analisis tersebut memberikan gambaran bahwa, kondisi dari factor -faktor yang menjadi pendorong (motivator ekstrisik) karyawan dalam bekerja seperti: gaji, tunjangan dan insentif, teman kerja, komunikasi, lingkungan, fasilitas serta keamanan kerja mendukung dan sesuai dengan harapan karyawan sehingga terwujudnya efektifitas dalam menjalankan tugas yang diembannya serta sesuai dengan sasaran dan tujuan pekerjaan, harapan organisasi terhadap mereka.

Demikian halnya dengan factor-faktor motivator intrisik seperti: Penghargaan terhadap potensi, kesesuaian pekerjaan dengan keterampilan dan tingkat pendidikan pegawai serta dengan diberikannya keleluasaan, otonomi, wewenang dan tanggung jawab dalam menyelesaikan pekerjaan merupakan factor motivator yang menjadi penggerak dalam diri karyawan atau pegawai dalam menjalankan tugas atau pekerjaanya sebagai abdi Negara.

Dalam kasus ini, anggota Badan Keswadayaan Masyarakat (BKM) pada program PNPM Mandiri Perkotaan Kota Mataram memberikan respon yang positif terhadap indicator-indikator motivasi kerja yang secara langsung berpengaruh pula terhadap adanya kinerja mereka. Motivasi merupakan hasrat di dalam anggota Badan Keswadayaan Masyarakat (BKM) yang menyebabkan para anggota Badan Keswadayaan Masyarakat (BKM) tersebut melakukan tindakan bagi lembaga Badan Keswadayaan Masyarakat (BKM). Motivasi mempersoalkan bagaimana caranya mendorong gairah kerja anggota, agar mau bekerja keras dengan memberikan semua kemampuan dan ketrampilannya untuk mewujudkan tujuan lembaga Badan Keswadayaan Masyarakat (BKM).

Kinerja berarti merupakan wujud hasil kerja yang dilakukan seseorang. Kinerja digunakan sebagai dasar penelitian sebagai dasar penilaian atau evaluasi dan sistem itu dapat merupakan kekuatan penting untuk mempengaruhi perilaku karyawan (Robbins, 1996). Hal ini sejalan dengan pendapat Robbins (1996) menyatakan bahwa dalam mempertahankan kelangsungan hidupnya, organisasi harus dapat mengembangkan potensi sumberdaya manusia hingga mampu menjalankan fungsinya sebagai mekanisme pembuat makna dan kendali yang nantinya akan memandu dan membentuk sikap serta perilaku pegawai. Robbins memberikan label faktor ini sebagai motivator karena masing-masing berhubungan dengan usaha yang kuat dan prestasi yang baik. Ia menghipotesiskan bahwa motivator menyebabkan seseorang berpindah dari suatu keadaan tanpa kinerja yang baik menjadi kinerja yang baik. Kunci dari teori Robbins adalah bagaimana mengembangkan potensi sumber daya manusia sehinga dapat menjalankan fungsinya secara maksimal.

Motivasi seorang berawal dari kebutuhan, keinginan dan dorongan untuk bertindak demi tercapainya kebutuhan atau tujuan. Hal ini menandakan seberapa kuat dorongan, usaha, intensitas, dan kesediaanya untuk berkorban demi tercapainya tujuan. Dalam hal ini semakin kuat dorongan atau motivasi kerja dan semangat akan semakin tinggi kinerjanya. 


\section{TMM JURNAL MAGISTER MANAJEMEN UNIVERSITAS MATARAM UNRAM VOL. 6 No. 1 MARET 2017}

Mangkunegara (2005:67) menyatakan faktor yang mempengaruhi kinerja adalah faktor kemampuan dan faktor motivasi. Sementara Malthis (2007)menyatakan kinerja yang dicari oleh perusahaan dari seseorang tergantung dari kemampuan, motivasi, dan dukungan individu yang diterima. Menurut Munandar (2001) ada hubungan positif antara motivasi dan kinerja dengan pencapaian kinerja individu, artinya karyawan yang mempunyai motivasi kerja yang tinggi cenderung mempunyai kinerja tinggi, sebaliknya mereka yang mempunyai kinerja rendah dimungkinkan karena motivasinya rendah.

\subsubsection{Pengaruh Dominan Motivasi Kerja Terhadap Kinerja Anggota.}

Hipotesis yang menyatakan motivasi kerja berpengaruh dominan terhadap kinerja anggota Badan Keswadayaan Masyarakat (BKM) pada program PNPM Mandiri Perkotaan Kota Mataram diterima. Berdasarkan hasil analisis menunjukkan bahwa motivasi kerja berpengaruh singifikan dan lebih dominan $\left(\mathbf{r}^{2}\right)$ dari komitmen organisasional terhadap kinerja anggota. Motivasi merupakan variabel penting, dimana motivasi perlu mendapat perhatian yang besar pula bagi lembaga dalam peningkatan kinerja anggotanya. Motivasi merupakan hasrat di dalam seseorang yang menyebabkan orang tersebut melakukan tindakan. Seseorang sering melakukan tindakan untuk suatu hal mencapai tujuan. Motivasi mempersoalkan bagaimana caranya mendorong gairah kerja bawahan, agar mereka mau bekerja keras dengan memberikan semua kemampuan dan ketrampilannya untuk mewujudkan tujuan perusahaan.

Motivasi seorang berawal dari kebutuhan, keinginan dan dorongan untuk bertindak demi tercapainya kebutuhan atau tujuan. Hal ini menandakan seberapa kuat dorongan, usaha, intensitas, dan kesediaannya untuk berkorban demi tercapainya tujuan. Dalam hal ini semakin kuat dorongan atau motivasi dan semangat akan semakin tinggi kinerjanya. Mangkunegara (2005:67) menyatakan faktor yang mempengaruhi kinerja adalah faktor kemampuan dan faktor motivasi. Sementara Mathis (2007:84) menyatakan kinerja yang dicari oleh perusahaan dari seseorang tergantung dari kemampuan, motivasi, dan dukungan individu yang diterima. Hasil penelitian inikonsisten dengan penelitian Emeka (2015),Nizam (2015) dan Muogbo (2013)yang menyatakan bahwa motivasi berpengaruh sifnifikan terhadap kinerja karyawan.

\section{KESIMPULAN DAN SARAN}

\subsection{Kesimpulan}

\section{Kesimpulan Deksriptif}

Berdasarkan hasil pembahasan variabel penelitian secara diskriptif dapat disimpulkan bahwa : 1) Komitmen organisasional anggota Badan Keswadayaan Masyarakat (BKM) pada program PNPM Kota Mataram dinyatakan cukup tinggi diterapkan dengan baik oleh anggota PNPM Mandiri Perkotaan Kota Mataram dalam bekerja di BKM. 2) Motivasi kerja anggota Badan Keswadayaan Masyarakat (BKM) pada program PNPM Kota Mataram dinyatakan tinggi, sehingga anggota bersemangat melaksanakan pekerjaan selama menjadi anggota Badan Keswadayaan Masyarakat (BKM) pada program PNPM Mandiri Perkotaan kota Mataram. 3)Kinerja anggota Badan Keswadayaan Masyarakat (BKM) pada program PNPM Kota Mataram dinyatakan 


\section{TMM JURNAL MAGISTER MANAJEMEN UNIVERSITAS MATARAM UNRAM VOL. 6 No. 1 MARET 2017}

sangat tinggi dalam bekerja pada PNPM Mandiri Perkotaan Kota Mataram dalam bekerja di BKM.

2. Kesimpulan Stasistik

Hasil penelitian yang telah dilakukan pada bab sebelumnya, maka dapat ditarik beberapa kesimpulan sebagai berikut:

1. Secara keseluruhan koefisien regresi variabel independen bertanda positif. Ini berarti hasil koefisien regresi sesuai harapan teoritis atau dengan kata lain apabila variable komitmen organisasional, motivasi kerja ditingkatkan maka kinerja anggota Badan Keswadayaan Masyarakat (BKM) pada program PNPM Kota Mataramakan meningkat. Dari hasil uji F diketahui bahwa nilai F hitung adalah sebesar 49,128, jika dibandingkan dengan nilai $\mathrm{F}$ tabel pada taraf $5 \%(2,710)$ nilai $\mathrm{F}$ hitung lebih besar dari F tabel. Dengan demikian, hipotesa pertama yang menyatakan terdapat pengaruh yang positif dan signifikan secara simultan dari komitmen organisasional dan motivasi kerja terhadap kinerja anggota Badan Keswadayaan Masyarakat (BKM) pada program PNPM Mandiri Perkotaan Kota Mataram terbukti kebenarannya.

2. Hasil perhitungan uji $t$, diketahui bahwa nilai masing-masing variable komitmen organisasional dan motivasi kerjasebagai berikut : komitmen organisasional $(\mathrm{X} 1)$ sebesar 0,354 ( $\operatorname{sig} \mathrm{t}=0,000<0,05)$, motivasi kerja $(\mathrm{X} 2)$ sebesar 0,467 (sig $\mathrm{t}=0,000<0,05$ ). Nilai $\mathrm{t}$ hitung ini memberi makna bahwa secara parsial komitmen organisasional dan motivasi kerjatersebut berpengaruh secara signifikan terhadapkinerja anggota. Dengan demikian hipotesis yang menyatakan komitmen organisasional dan motivasi kerja secara parsial mempunyai pengaruh yang signifikan terhadap kinerja anggota

Badan Keswadayaan Masyarakat (BKM) pada program PNPM Mandiri Perkotaan Kota Mataram terbukti kebenarannya.

3. Untuk membuktikan hipotesis ketiga, yang menyatakan bahwa variable motivasi kerja yang paling dominan mempengaruhi kinerja anggota Badan Keswadayaan Masyarakat (BKM) pada program PNPM Mandiri Perkotaan Kota Mataram diterima. Hasil perhitungan koefisien determinasi (r2) parsial dari variable komitmen organisasional yaitu 0,606 lebih besar dari variable motivasi kerja (r2 = 0,433). Hal ini memberi makna bahwa variable komitmen organisasional berpengaruh secara signifikan dan dominan terhadap kinerja anggota. Dengan demikian hipotesis tersebut dapat diterima.

\subsection{Saran}

Berdasarkan hasil penelitian dan beberapa kesimpulan yang dikemukakan di atas, maka disarankan beberapa hal sebagai berikut:

1. Variabel motivasi kerja merupakan faktor dominan yang mempengaruhi kinerja anggota Badan Keswadayaan Masyarakat (BKM). Ini berarti tinggi rendahnya kinerja anggota sangat dipengaruhi oleh motivasi kerja. Oleh karena itu, pimpinan dan pengelola lembaga Badan Keswadayaan Masyarakat (BKM) harus memeperhatikan unsur-unsur yang dapat meningkatkan motivasi kerja mereka seperti:perhatian terhadap capaian prestasi kerja anggota, target dalam pekerjaan, kesesuaian antara pekerjaan dengan rencana, mengembangkan kelompok kerja serta memperhatikan kepentingan pribadi anggota Badan Keswadayaan Masyarakat (BKM) 


\section{TMM JURNAL MAGISTER MANAJEMEN UNIVERSITAS MATARAM UNRAM VOL. 6 No. 1 MARET 2017}

2. Komitmen organisasional berdasarkan tanggapan responden menunjukan kategori yang relaitif cukuptinggi. Artinya masih terdapat beberapa komponen indikator komitmen organisasional yang seharusnya menjadi perhatian organisasi khususnya pimpinan atau pengelola Badan Keswadayaan Masyarakat (BKM) pada program PNPM Mandiri Perkotaan Kota Mataram. Hal tersebut dapat dilakukan dengan cara lebih memperhatikan kebijakan-kebijakan terkait dengan penguatan komitmen orginasional anggota terhadan lembaga seperti: kesempatan untuk berkreatif dan berinovasi, ketersediaan fasilitas dan peralatan kerja, hubungan kerja antar sesama rekan sekerja, sehingga komitmen organisasional anggota Badan Keswadayaan Masyarakat (BKM) pada program PNPM Mandiri Perkotaan Kota Mataram bertambah meningkat.

\section{DAFTAR PUSTAKA}

Alwi, S. (2001), Manajemen Sumber Daya Manusia, Strategi Keunggulan Kompetitif,Yogyakarta: Badan Penerbit Fakultas Ekonomi.

Anggoro, P.,\& Widiyanti, N. (1993),Psikologi Dalam Perusahaan, Interaksi Sosial, Jakarta: Rineka Karya.

., (2004),Manajemen Bisnis,Jakarta: Rineka Cipta. (2014), Psikologi Kerja,Jakarta:Rineka Cipta.

Arikunto,\& Suharsimi, (1998),Prosedur Penelitian Suatu Pendekatan Praktek, Jakarta: PT. Rineka Cipta.

Bernardin, H. J., \& Joyce, E. A. (1993), Human Resources Management, An Experiantial Approach, New York:Mc Graw-Hill, Inc.

Cascio, W. F.(1992),Managing Human Resource Productivity, Quality of work Life, Profit,Singapore:Mc Graw-Hill Book, Co.

Dessler, G.(1997),Manajemen Personalia,(edisi ketiga), Terjemahan. Jakarta: Erlangga.

Emeka, N. (2015),"The Effect of Employee Motivation on Organizational Performance of Selected Manufacturing Firms in Enugu State", World Journal of Management and Behavioral Studies,3(1)

Fitrie, S. (2008), "Pengelolaan Keuangan Daerah Persfektif PermendagriNomor 13 tahun 2006 Pada Pemerintah Kota Binjai". Tesis, Program Pasca Sarjana USU, Medan.

Gibson., Ivancevich., \&Donnelli, (1999),Organisasi - Perilaku - Struktur - Proses, Jilid I, Edisi Kedelapan, Jakarta: Bina Rupa Aksara.

(1997),Organisasi dan Manajemen, Perilaku, Struktur, Proses, Edisi Ke - Empat, , Jakarta : Airlangga.

. (1984), Organisasi dan Manajemen :Perilaku, Sruktur, dan Proses. Edisi Keempat. Jakarta: Erlangga

Gomes, F.C. (1999), Manajemen Sumber Daya Manusia", Yogyakarta: Andi Offset.

Gouzali, S. (2005), Manajemen Sumber daya Manusia: Suatu pendekatan Mikro, Jakarta: Djambaran.

Handoko, T. H. ( 2001),Manajemen Personalia dan Sumberdaya Manusia,Edisi Kedua. Yogyakarta: BPFE.

.(2000), Manajemen Personalia Dan Sumberdaya Manusia, Yogyakarta: BPFE.,

Hasibuan, S.P.,\& Malayu, (2002),Manajemen Sumber Daya Manusia, Edisi Revisi. Cetakan Kelima. Jakarta: Penerbit PT. Bumi Aksara.

Respatiningsih,I. (2015), “Pengaruh Komitmen Organisasi, Motivasi, Kapabilitas Dan Kepuasan Kerja Terhadap Kinerja Karyawan(Studi Empirik Pada Inspektorat Kabupaten Pemalang)",Jurnal Ilmiah UNTAG,4(3) 


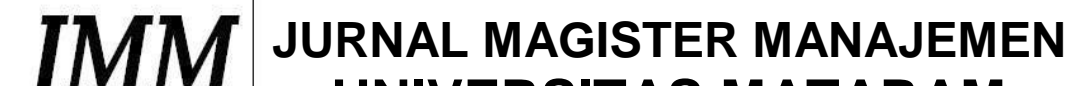 UNIVERSITAS MATARAM UNRAM VOL. 6 No. 1 MARET 2017}

Irefin, P. (2014), "Effect of Employee Commitment on Organizational Performance in Coca Cola Nigeria Limited Maiduguri, Borno State",IOSR Journal Of Humanities And Social Science (IOSR-JHSS), 19(3), 33-41

Jensen, M. C., \& Meckling, W.H. (1976), "Theory of the Firm : Managerial Behavior, Agency Costs and Ownership Structure ". Journal of Financial Economics, 3(4), 305-360.

John, M. C., \&John, W.T.(2003), 'Leadership Style, School Climate, and the Institutional Commitment of Teachers". Dissertation, Doctoral in Seventh-Day Adventtist Secondary Schools, in Philippines.

Mangkunegara, A. P.(2009), Manajemen Sumber Daya ManusiaPerusahaan, Cetakan Keenam, Bandung: PT. Remaja Rosdakarya.

(2007),Manajemen Sumber Daya Manusia,Bandung: Pustaka Setia .(2006),Manajemen Sumber Daya Manusia, Bandung: Remaja Rosdakarya

Mangkuprawira, S., \& Hubeis, A.V. (2007), Manajemen Mutu Sumber Day Manusia, Bogor:

Ghalia Indonesia.

Mathis, R., \&Jackson, J. H. (2001),Manajemen Sumber Daya Manusia, Edisi Pertama, Jakarta: Salemba Empat.

Meyer, J.P.„\& Allen, N. J.(1991),“A Three Component Conceptualization of Organizational Commitment",Human Resources Management Review, the University of Western Ontario. 1 (1).

(1993),"A Three Component Conceptualization of Organizacional Commitment". Human Resources Management Review, the University of Western Notario. 1 (1)

Muogbo, (2013), "The Impact of Employee Motivation On Organisational Performance (A Study Of Some Selected Firms In Anambra State Nigeria)", The International Journal Of Engineering And Science (IJES),II (7), 70-80

Rivai, H. A.(2001), "Pengaruh Kepuasan Gaji, Kepuasan Kerja, dan Komitmen Organisasional Terhadap Intensi Keluar". Tesis, Universitas Gajah Mada Yogyakarta.

PNPM. (2016), “ BKM Kota Mataram”, wwww.p2kp.org/datapnpmt

Rizal, M.(2014), "Effect of Compensation on Motivation, Organizational Commitment and

Employee Performance (Studies at Local Revenue Management in Kendari

City)", International Journal of Business and Management Invention, III (3), 64-79

Roberts, Karlene H and David M. Hunt, (1991). Organizational Behavior, $2^{\text {nd }}$ Ed. Pws-Kent Publishing Company, Boston.

Simanjuntak, P. J.(2005),Manajemen dan Evaluasi Kerja,Jakarta: Lembaga Penerbit FEUI.

Steers, R. M.(2005),Efektivitas Organisas", Terjemahan. Jakarta: Erlangga

Stoner, J.A.F., R. Feeman, E. \&Danier, R. G. Jr. (1996), Manajemen, Jakarta: Jilid II, Penerbit Prenhalindo

Sunyoto, D. (2012),Manajemen Sumber Daya Manusia, Yogyakarta : CAPS

Suprihanto, J., Harsiwi A.,\&Prakoso, H.(2002),Perilaku Organisasional,Yogyakarta: Cetakan

Pertama. ISBN 979-8146-73-5. Penerbit Sekolah Tinggi Ilmu Ekonomi

(2003),Prilaku Organisasi,Yogyakarta: Jilid I, Edisi ke-1, STIE YKPN.

Warisno, (2009), “Faktor-faktor yang Mempengaruhi Kinerja SKPD di Lingkungan

Pemerintah Provinsi Jambi".Tesis. Program Pasca Sarjana USU, Medan.

Yount, Mark A., et al (1996),"Human Resource Management Manufacturing Strategy, and Firm Performance", JournalAcademy of Management, 39 (4). 